A N N A L E S

UN IVER S T ATIS M A R I E C URIE-SKŁODOW S A

LUBLIN - POLONIA

VOL. XXXI, 3

SECTIO J

2018

Uniwersytet Marii Curie-Skłodowskiej w Lublinie. Wydział Pedagogiki i Psychologii

\title{
ŁUCJA DOMAŃSKA
}

ORCID: 0000-0002-2064-8053

1.domanska@poczta.umcs.lublin.pl

\section{Depresja wieku podeszłego - wyzwania diagnostyczne}

Late-life Depression - Diagnostic Challenges

\section{STRESZCZENIE}

Depresja wieku podeszłego stanowi poważny i nasilający się w skali społecznej problem, choć w praktyce wydaje się on zbyt rzadko diagnozowany. Podwyższa ona wskaźniki śmiertelności, wiąże się z niepomyślnym przebiegiem schorzeń somatycznych, nasila niepełnosprawność i prowadzi do utraty samodzielności, wpływając na jakość życia pacjentów i ich bliskich. Zaburzenie to stanowi wyzwanie na etapie diagnozowania ze względu na maskowanie objawów depresyjnych przez inne problemy natury psychologicznej i zdrowotnej występujące w tym okresie życia. W artykule zarysowano specyfikę obrazu klinicznego depresji wieku podeszłego i psychospołeczny kontekst jej ujawniania. Wskazano na rodzaj trudności diagnostycznych i ich uwarunkowania. Scharakteryzowane zostały zaburzenia poznawcze występujące w przebiegu depresji, z uwzględnieniem tzw. depresyjnego zespołu dysfunkcji wykonawczych. Sformułowano też zalecenia dotyczące monitorowania stanu funkcji poznawczych starszych pacjentów z rozpoznaniem depresji.

Slowa kluczowe: depresja; wiek podeszły; zaburzenia poznawcze; depresyjne dysfunkcje wykonawcze; depresja poudarowa

\section{WPROWADZENIE}

Ocenia się, iż depresja jest drugą pod względem częstości (po chorobie niedokrwiennej serca) przyczyną niepełnosprawności w populacji ogólnej. Wśród osób starszych jest drugim najczęściej występującym, po otępieniu, zaburzeniem psychicznym (za: Osińska i in. 2017). Wiąże się z: niższym poziomem aktywności fizycznej i społecznej; słabszą współpracą z lekarzem w toku działań 
diagnostycznych i leczących; podwyższonym ryzykiem uzależnienia od leków przeciwbólowych i nasennych; gorszymi rokowaniami u pacjentów zmagających się z chorobami somatycznymi; istotnie podwyższonym ryzykiem śmierci uwarunkowanej różnymi czynnikami (Manthorpe, Iliffe 2010). Depresja powoduje cierpienie w wymiarze jednostkowych przeżyć samego chorego, ale także jego bliskich oraz osób zapewniających profesjonalne wsparcie i opiekę, zatem stanowi poważny problem w skali społecznej.

Depresja wieku podeszłego (late-life depression - LLD) najczęściej jest rozumiana jako heterogeniczne zaburzenie afektywne występujące u osób powyżej 60. r.ż. (Koenig, Bhalla, Butters 2014; Richard, Satahta 2004). Określeniem tym obejmowane są osoby, u których depresja stanowi kontynuację zaburzeń ujawnionych już we wcześniejszym okresie rozwoju, jak również te, u których epizody depresyjne ujawniły się po raz pierwszy po 60. r.ż. (late-onset depression-depresja o późnym początku). Wyodrębnienie depresji wieku podeszłego w analizach i pracach badawczych podyktowane jest z jednej strony społeczną skalą proble$\mathrm{mu}$, a z drugiej swoistymi cechami uwarunkowań oraz specyfiką obrazu klinicznego i postępowania terapeutycznego.

Szacunki dotyczące występowania problemu depresji ogólnie wskazują na większą częstość ujawniania tego typu zaburzeń przez osoby starsze w porównaniu do wcześniejszego okresu życia, przy czym stwierdzona w wieku średnim dysproporcja między liczbą rozpoznań depresji u kobiet i mężczyzn (tj. większa częstość występowania tego problemu u kobiet) nie znajduje potwierdzenia w większości badań populacji w podeszłym wieku (Steffens i in. 2009). W grupie osób starszych wartości wskaźników występowania depresji wahają się od kilku do kilkudziesięciu procent populacji. Zróżnicowanie to wynika z zastosowania przez badaczy odmiennych podejść metodologicznych, procedur badawczych (np. sposobów kwalifikowania osób do badań), zastosowanych narzędzi i przyjętych założeń dotyczących kryteriów rozpoznania zaburzeń (np. duża depresja vs. objawy depresyjne). I tak np. na podstawie oceny realizowanej w toku praktyki lekarza rodzinnego rozpoznano zaburzenia depresyjne u ponad $17 \%$ pacjentów powyżej 75. r.ż., w tym u ponad 3\% nasilenie objawów określono jako ciężkie (Bujnowska-Fedak, Grata-Borkowska, Sapilak 2012). W badaniach przeprowadzonych w środowisku wiejskim lekkie objawy depresji stwierdzono u ponad $46 \%$ seniorów, natomiast ciężkie zaburzenia - u prawie 11\% (Kujawska-Danecka i in. 2016). U mieszkańców domów pomocy społecznej powyżej 70. r.ż. cechy depresyjne o nasileniu umiarkowanym rozpoznano u około $21 \%$ kobiet i $22 \%$ mężczyzn, a o nasileniu głębokim - u około 11\% kobiet i 6\% mężczyzn (Nowak-Kapusta i in. 2017). Ujawnianie objawów depresji przez osoby starsze objęte pielęgniarską domową opieką długoterminową oszacowano z uwzględnieniem bardziej szczegółowych przedziałów wiekowych. Wskazano na największy odsetek występowania objawów depresji (50\%) w grupie 65-75 lat, w przedziale 
76-90 lat problem zaznaczył się u ponad 34\% badanych, zaś powyżej 90. r.ż. u około 20\% (Irzyniec i in. 2016). Doświadczanie dolegliwości somatycznych, korzystanie z pomocy lekarza podstawowej opieki zdrowotnej i niemożność opuszczania swojego mieszkania (ograniczona mobilność) wydają się charakterystykami sprzyjającymi depresji w populacji osób starszych (por. Manthorpe, Iliffe 2010).

\section{UWARUNKOWANIA DEPRESJI WIEKU PODESZŁEGO}

W analizach zaburzeń depresyjnych okresu senioralnego zwraca się uwagę na współwystępowanie wielu czynników etiologicznych w różnym stopniu determinujących funkcjonowanie osoby. Są to czynniki natury biologicznej oraz psychospołecznej. Wśród biologicznych najczęściej wymieniane są: czynniki genetyczne; zmiany związane z procesem starzenia się; schorzenia somatyczne prowadzące do rozwoju objawów depresyjnych poprzez zaburzenia metabolizmu tkanki nerwowej; stosowane leki (m.in. statyny, niektóre z leków przeciwnadciśnieniowych, hormonalnych, przeciwpadaczkowych) (Dobrzyńska, Rymaszewska, Kiejna 2007).

W psychologicznych analizach uwarunkowań depresji wieku podeszłego uwzględniane są straty w sferze zdrowotnej, społecznej i ekonomicznej ponoszone w tym okresie ontogenezy. Wśród obciążeń zdrowotnych, obok pogorszenia czynności fizjologicznych organizmu i osłabienia narządów zmysłów, wymienia się takie choroby, jak: choroba niedokrwienna serca, choroba zwyrodnieniowa stawów, choroby nowotworowe, cukrzyca typu 2, zaburzenia hormonalne, zaburzenia neurodegeneracyjne, uszkodzenia mózgu pochodzenia naczyniowego. Są to schorzenia uciążliwe z perspektywy codziennego funkcjonowania, prowadzące (bezpośrednio lub poprzez powikłania) do niepełnosprawności oraz zagrażające życiu. Wyzwania, przed którymi stają osoby starsze, obejmują: pogarszającą się sprawność ruchową, trudności w wykonywaniu codziennych czynności, utratę niezależności życiowej; mniejszą wydolność w wykonywaniu pracy zawodowej, konieczność rezygnacji z niej; śmierć przyjaciół, utratę partnera życiowego. Ustaniu aktywności zawodowej może towarzyszyć poczucie izolacji społecznej i utraty statusu społecznego, a także pogorszenie warunków ekonomicznych życia. Pogorszenie stanu somatycznego i nasilenie ogólnych problemów zdrowotnych może wzmacniać pesymistyczne myśli prowadzące do poczucia beznadziejności i obniżonej samooceny, a w konsekwencji predysponować do zaburzeń depresyjnych (Steuden 2011).

Straty, ponoszone zarówno w sferze zdrowotnej, jak i społecznej czy ekonomicznej, nie mogą być traktowane jako prowadzące w sposób bezpośredni do depresji. Charakterystyki psychologiczne warunkujące radzenie sobie w toku procesu starzenia się obejmują m.in.: poziom doświadczanego stresu; znaczenie, 
jakie osoba przypisuje swojej chorobie i niesprawności; styl i strategie radzenia sobie z sytuacjami trudnymi; mechanizmy obronne chroniące przed lękiem; poczucie koherencji. Istotną rolę odgrywają również zmienne społeczne: wpływ otoczenia; sytuacja rodzinna (np. choroba bliskiej osoby, sprawowanie opieki nad przewlekle chorym małżonkiem); uzyskiwane wsparcie; podtrzymywanie kontaktów interpersonalnych (por. Heszen, Sęk 2000; Steuden 2011). W przypadku np. zależności między nasileniem niesprawności a obecnością zmian nastroju nie wszystkie doniesienia potwierdzają, iż ograniczenia aktywności - nawet znaczne uzależnienie w czynnościach samoobsługowych od personelu pielęgniarskiego podwyższają jednoznacznie wskaźniki depresji (Zarb 1996). Dodatkowo stwierdzane związki korelacyjne mogą odzwierciedlać dwukierunkowe oddziaływania - osoby z bardziej nasiloną niesprawnością mogą wykazywać z tego powodu większą depresję, ale sama depresja jest też jednym z czynników nasilających niesprawność (Dobrzyńska, Rymaszewska, Kiejna 2007; Steuden 2011).

\section{SPECYFIKA OBRAZU KLINICZNEGO DEPRESJI WIEKU PODESZŁEGO}

W diagnozowaniu zaburzeń depresyjnych stosowane są kryteria Międzynarodowej Klasyfikacji Chorób (ICD-10 1998) oraz Amerykańskiego Towarzystwa Psychiatrycznego (DSM-5 2013). W obowiązującej w Polsce klasyfikacji ICD-10 wyróżniono objawy podstawowe i dodatkowe pozwalające rozpoznać i scharakteryzować nasilenie nieprawidłowości. Za symptomy podstawowe uznano: obniżenie nastroju, utratę zainteresowań, zmniejszoną energię i nasiloną męczliwość. Objawy dodatkowe obejmują: niską samoocenę i poczucie winy, myśli/zachowania samobójcze, osłabienie funkcji poznawczych, zmiany w zakresie aktywności psychoruchowej, zaburzenia snu, zmiany łaknienia powiązane ze zmianą wagi ciała. Rozpoznanie depresji wymaga spełnienia (a) kryteriów objawowych (u pacjenta muszą wystąpić przynajmniej dwa z trzech objawów podstawowych oraz symptomy dodatkowe, dopełniające łączną liczbę objawów do co najmniej czterech) oraz (b) kryteriów czasowych (epizod trwa przynajmniej dwa tygodnie).

Obraz kliniczny depresyjnych zaburzeń nastroju u osób w późnym okresie życia może różnić się od tego, który ujawniają osoby młodsze. Odmienność nie wynika z obecności charakterystycznych „,dodatkowych” objawów, lecz z większego nasilenia oraz częstszego występowania niektórych z nich (Filipska $i$ in. 2015). Uczucie smutku ujawniane jest rzadziej niż w depresji wieku średniego. Za częsty uznaje się natomiast przebieg z dużym lękiem i niepokojem (Manthorpe, Iliffe 2010). Wyraźnie mogą zaznaczać się: pobudzenie, drażliwość, nietypowe dla danej osoby sposoby wyrażania emocji, zakłócenia funkcji poznawczych, dolegliwości somatyczne, spadek libido, bezsenność i poczucie zmęczenia (Hegeman i in. 2012). Zgłaszane liczne skargi somatyczne dotyczą najczęściej: 
pracy jelit, bólu pleców i głowy. Doznania bólowe w obrazie depresji najczęściej mają charakter przewlekły, bez promieniowania, występują często w godzinach nocnych i porannych, wykazują oporność w stosunku do farmakoterapii.

Lękowy i somatyczny rys zaburzeń depresyjnych wieku podeszłego jest źródłem trudności diagnostycznych. Symptomy mogą być mylnie postrzegane nie jako przejaw zaburzeń depresyjnych, lecz jako integralnie związane z innymi obciążeniami tego okresu. Proces diagnozowania może być więc błędnie ukierunkowywany na zaburzenia lękowe lub schorzenia somatyczne, takie jak: choroby serca, układu pokarmowego, nowotwory, schorzenia kręgosłupa. Nieuwzględnianie w toku diagnozy innych uwarunkowań dolegliwości fizycznych niż somatyczne może zdarzać się szczególnie w przypadku osób, u których już wcześniej rozpoznano choroby somatyczne o postępującym przebiegu, z powikłaniami, a zastosowana farmakoterapia niesie ryzyko niepożądanych skutków ubocznych.

Objawy depresyjne u seniorów bywają traktowane również jako normalne reakcje emocjonalne na niesprawność $i$ inne straty ponoszone $w$ różnych wymiarach życia w późnym okresie ontogenezy. Utrzymujące się przez długi czas cechy obniżenia nastroju, poprzez swą przewlekłość, mogą być odbierane jako trwałe charakterystyki osobowości jednostki, typowe dla niej i w związku z tym niebudzące zaniepokojenia. Ryzyko zlekceważenia objawów występuje zwłaszcza wówczas, gdy wpisujące się w depresję takie cechy, jak wyciszenie, apatyczność czy nieabsorbowanie sobą, nie komplikują relacji z innymi, a w niektórych przypadkach ułatwiają sprawowanie opieki nad osobą (Manthorpe, Iliffe 2010). Wymienione utrudnienia w identyfikowaniu zaburzeń depresyjnych wieku podeszłego w opinii zarówno badaczy, jak i praktyków przyczyniają się do niedoszacowania problemu i zbyt rzadkich rozpoznań, a w konsekwencji prowadzą do wdrażania niepotrzebnych badań dodatkowych i podejmowania niewłaściwego leczenia (Colasanti i in. 2010; Hegeman i in. 2012).

Szacuje się, iż od 20\% do 50\% starszych osób z depresją ujawnia większe obniżenie funkcjonowania poznawczego niż grupa odniesienia bez depresji zrównana pod względem wieku i wykształcenia (Koenig, Bhalla, Butters 2014). Biorąc pod uwagę współwystępowanie u seniorów zaburzeń poznawczych z depresją, podejmuje się próby opisania natury tego powiązania. Zakłócenia poznawcze często są traktowane jako integralny element obrazu klinicznego depresji. Za takim ujęciem wydaje się przemawiać fakt, iż u części pacjentów odnoszących korzyści z leczenia przeciwdepresyjnego odnotowywana jest równocześnie poprawa w zakresie funkcjonowania poznawczego. Jednakże mimo skutecznego leczenia przeciwdepresyjnego u stosunkowo dużej grupy chorych utrzymuje się obniżony poziom funkcjonowania poznawczego (nawet u 94\% według niektórych źródeł; zob. Bhalla i in. 2006). Co więcej, u pacjentów pierwotnie poznawczo niezaburzonych mogą ujawnić się deficyty poznawcze po przeprowadzeniu skutecznego leczenia przeciwdepresyjnego (po roku u 23\%) (Bhalla i in. 2006). Wydaje się 
więc, iż zakłócenia poznawcze mogą mieć charakter względnie niezależny od depresji, mogą wynikać $\mathrm{z}$ innego toczącego się w organizmie procesu chorobowego obejmującego mózg.

Charakterystyki poznawczego funkcjonowania w depresji wieku podeszłego obejmują: zaburzenia uwagi, pamięci, funkcji wzrokowo-przestrzennych; małą szybkość przetwarzania informacji; osłabienie kontroli i elastyczności poznawczej. W depresji o późnym początku szczególnie wyraziście wydają się zaznaczać deficyty funkcji wykonawczych i uwagi (Herrmann, Goodwin, Ebmeier 2007; Janssen i in. 2007; Rataj-Zembaty i in. 2017), które opatruje się określeniem depresyjnego zespołu dysfunkcji wykonawczych wieku podeszłego (depressionexecutive dysfunction syndrome of late life - DED). Obraz zakłóceń cechuje:

- osłabienie inicjowania działania i jego kontroli w postaci trudności w rozpoczynaniu, kontynuowaniu działania, przełączaniu między zadaniami, planowaniu oraz hamowaniu,

- spowolnienie psychoruchowe, słabsza elastyczność poznawcza, gorsza fluencja semantyczna, mniej efektywne wygaszanie automatycznych reakcji motorycznych (Alexopoulos i in. 2005; Rajtar-Zembaty i in. 2017).

Deficyty wykonawcze mogą zakłócać sposób funkcjonowania emocjonalnego osoby. Utrata możliwości sprawnego i skutecznego koordynowania działań na drodze do osiągnięcia celu może nasilać poczucie bezradności, a także (w odleglejszej perspektywie) prowadzić do utraty zainteresowań. Charakterystyczne dla dysfunkcji wykonawczych trudności w uruchamianiu procesów hamowania (tj. wygaszaniu nieodpowiednich reakcji) sprzyjają zniekształceniom przetwarzanych informacji i w konsekwencji mogą przyczyniać się do osłabienia możliwości kontrolowania ruminacyjnych myśli. Deficyty wykonawcze doprowadzają do zakłócenia regulacji emocjonalnej poprzez poczucie nieradzenia sobie i ocenę sytuacji jako przekraczającej możliwości jednostki. Depresyjny zespół dysfunkcji wykonawczych wieku podeszłego jest podstawą formułowania złych rokowań - pacjenci wykazują słabszą i odroczoną w czasie odpowiedź na leczenie przeciwdepresyjne oraz ujawniają wyższy wskaźnik nawrotów (Alexopoulos i in. 2005).

\section{DEPRESJA WIEKU PODESZŁEGO A OTĘPIENIE}

Osłabienie funkcji poznawczych w depresji może przyjmować uogólnioną postać. Określenia „pseudodemencja” czy „demencja rzekoma” są odzwierciedleniem trudności diagnostycznych wynikających z faktu, iż objawy depresji mogą przypominać i sugerować otępienie (por. Dobrzyńska, Rymaszewska, Kiejna 2007). Apatia, spowolnienie psychoruchowe, zaburzenia pamięci czy uwagi, spadek zainteresowań, zobojętnienie - to charakterystyki, które współtworzą obraz depresji, ale również mogą wpisywać się w proces dementywny (Barnes i in. 
2012; Diniz i in. 2013; Jodzio, Wieczorek, Radziwiłłowicz 1997; Richard, Satahta 2004). Niektóre cechy funkcjonowania pacjentów mogą pomóc różnicować te dwa problemy kliniczne.

W procesie otępiennym (np. typu Alzheimerowskiego) charakterystyczny jest powolny, skryty początek, podczas gdy w zaburzeniach depresyjnych zazwyczaj jest on wyraźnie zaznaczony. Pacjenci depresyjni szczegółowo relacjonują dolegliwości, zaś osoby z otępieniem zgłaszają dość ogólnie sformułowane skargi. Nastrój w depresji jest względnie stabilnie obniżony w pewnej jednostce czasu; pacjenci z otępieniem częściej ujawniają zmienność w zakresie reakcji emocjonalnych. Osoby depresyjne wkładają niewielki wysiłek w realizację zadań dnia codziennego (a także $\mathrm{w}$ te związane $\mathrm{z}$ udziałem w badaniach diagnostycznych), w jawny sposób „wypadają" z dotychczasowych ról społecznych, nie wywiązują się ze swoich obowiązków. Natomiast pacjenci na początku procesu dementywnego podejmują zauważalny (choć nie zawsze skuteczny) wysiłek, aby sprostać wyzwaniom, często próbują maskować swoje trudności, starając się kontynuować dotychczasową aktywność (np. zawodową). W związku z tym odpowiedzi „nie wiem" mogą częściej pojawiać się w wypowiedziach osób z depresją niż z otępieniem w początkowym stadium. W tym drugim przypadku pacjenci podejmują próbę odpowiedzi na pytania czy znalezienia rozwiązania problemu, choć najczęściej popełniają błędy. Dla pacjentów z depresją charakterystyczne są zmienne wyniki uzyskiwane $\mathrm{w}$ toku oceny neuropsychologicznej, natomiast osoby z demencją ujawniają w kolejnych badaniach pogarszające się funkcjonowanie. W depresji rzadziej niż na początku otępienia wykazywane jest przez chorych zainteresowanie diagnozowaniem i leczeniem. Poprawa stanu chorego zdarza się istotnie częściej w zaburzeniach afektywnych (w następstwie wdrożonego leczenia przeciwdepresyjnego), a w przebiegu otępienia z reguły nie występuje (Dobrzyńska, Rymaszewska, Kiejna 2007; Parnowski 2011).

Proces różnicowania depresji i otępienia dodatkowo komplikowany jest możliwością współwystępowania obu tych problemów klinicznych. Depresja pogłębia wówczas zaburzenia poznawcze, a otępienie może sprawiać wrażenie głębszego, niż jest w rzeczywistości (Dobrzyńska, Rymaszewska, Kiejna 2007).

\section{DEPRESJA W PRZEBIEGU CHORÓB NACZYNIOWYCH MÓZGU}

Zaburzenia depresyjne u osób starszych obciążonych dysfunkcjami naczyniopochodnymi mózgu są dobrą ilustracją kliniczną zarysowanych wyżej trudności diagnostycznych i terapeutycznych.

Objawy depresyjne uwikłane w obraz choroby naczyniowej mózgu mogą ujawniać się w różnych okresach jej przebiegu. Bywają rejestrowane u pacjentów przed wystąpieniem uchwytnych oznak procesu udarowego i tworzą obraz tzw. depresji zwiastunowej, pozostającej w związku z „niemymi” udarami, przebie- 
gającymi bez symptomów klinicznych. Depresja może towarzyszyć pacjentom w naczyniopochodnym otępieniu, a więc współwystępować z wyrazistymi oznakami postępujących patologicznych zmian w mózgu. Cechy depresyjne ujawniane są także bezpośrednio po udarze (w ciągu pierwszych dni, kiedy obserwowana jest przewaga występowania problemu depresji w następstwie uszkodzeń lewopółkulowych) oraz w okresie późniejszym, w ciągu kilku lat od wystąpienia udaru (kiedy pacjenci z uszkodzeniami prawej półkuli wydają się bardziej narażeni na ujawnienie objawów depresyjnych) (Carson i in. 2000; Hackett i in. 2005; Kumar i in. 2010; Steuden 2011). Diagnozy najczęściej stawiane są w ciągu kilku pierwszych miesięcy od udaru, a kolejny wzrost rozpoznań datuje się na 2-3 lata po udarze. W depresji rozpoznanej w stosunkowo krótkim czasie po udarze deficyty ruchowe i poznawcze (ujawnione w konsekwencji naczyniopochodnego uszkodzenia ośrodkowego układu nerwowego) słabiej korelują z nasileniem objawów depresyjnych niż w przypadku problemu depresji zdiagnozowanego w późniejszym okresie. Ta zmienność sugeruje zróżnicowaną naturę zaburzeń depresyjnych przejawianych na różnych etapach choroby i rekonwalescencji (Nys i in. 2006). Za udziałem czynnika psychologicznego w genezie problemu depresji przemawia większa skłonność do jego ujawnienia u pacjentów zaburzonych poznawczo po uszkodzeniu mózgu, którzy przedchorobowo reprezentowali wysoki poziom funkcjonowania intelektualnego (wyższy przedchorobowy status edukacyjny, zawodowy czy społeczny wiąże się z większym przygnębieniem i skrępowaniem swoimi kłopotami, np. z pamięcią). Podobną podatność zaobserwowano u chorych z zachowanymi werbalnymi zdolnościami abstrakcyjnego rozumowania, bardziej świadomych swych deficytów poznawczych, dla których przystosowanie do zmienionych możliwości funkcjonowania wydaje się szczególnie emocjonalnie trudne (Zarb 1996).

Zinstytucjonalizowana opieka, której wymaga część pacjentów po udarach, nie wydaje się jednoznacznie sprzyjać ujawnianiu depresji (Zarb 1996). Uzyskanie takiej opieki może być postrzegane jako droga mierzenia się z poważnymi wyzwaniami życiowymi i może stanowić wyraz skutecznego radzenia sobie z rozwiązywaniem praktycznych problemów. Czynnikiem chroniącym przed depresją okazuje się wsparcie społeczne, zwłaszcza otrzymywane dzięki kontaktom z osobami spoza kręgu najbliższej rodziny (za: Zarb 1996). Podtrzymywanie starych i budowanie nowych więzi jest źródłem znaczącego efektu buforowego.

Do typowych objawów depresji poudarowej należą: spowolnienie psychoruchowe, anhedonia, myśli samobójcze. Stosunkowo rzadko towarzyszy pacjentom poczucie winy. W obrazie klinicznym szczególnie wyraźnie zaznaczają się objawy somatyczne i poznawcze, jednak liczne skargi na dolegliwości somatyczne i trudności poznawcze są również zgłaszane przez osoby po udarze bez zaburzeń depresyjnych (Andersen i in. 1995). Niektóre z objawów udarowych, takie jak słaba ekspresja mimiczna, ograniczenie ekspresji słownej, utrata inicjatywy, re- 
akcje katastroficzne lub obojętność, nakładają się na symptomatologię depresyjną i - ,imitując” depresję - podwyższają ryzyko rozpoznań fałszywie pozytywnych. Odwrotny kierunek zniekształcenia procesu diagnozy (zbyt rzadkie rozpoznania depresji) wiąże się z efektem jej maskowania przez symptomy uszkodzenia mózgu (m.in. anozognozję, zaprzeczanie, aprozodię) oraz może wynikać z trudności w nawiązaniu kontaktu z pacjentem obciążonym np. deficytami afatycznymi.

\section{ZAKOŃCZENIE}

W porównaniu $\mathrm{z}$ wiekiem średnim depresji ujawnianej przez seniorów przypisuje się bardziej chroniczny charakter oraz traktuje się ją jako trudniejszą w leczeniu (m.in. z powodu obciążenia wielolekowością i w związku z ryzykiem polipragmazji). Stanowi ona wyzwanie nie tylko w toku oddziaływań terapeutycznych, ale również na etapie diagnozowania ze względu na jej maskowanie przez inne problemy natury psychologicznej i zdrowotnej. Somatyczne objawy depresji w przypadku osób starszych wydają się w związku z tym mniej specyficznymi wskaźnikami zaburzeń afektywnych niż symptomy niesomatyczne.

Nieleczona lub niewłaściwie leczona depresja wieku podeszłego prowadzi do negatywnych, często dramatycznych następstw. Najpoważniejszym z nich jest wysoka śmiertelność związana z aktami samobójczymi oraz niepomyślnym przebiegiem schorzeń somatycznych. Słaba współpraca z lekarzem nasila niepełnosprawność i prowadzi do utraty samodzielności. Uogólnione pogorszenie funkcjonowania wpływa na jakość życia osoby i jej bliskich.

Istotne znaczenie dla planowanej terapii ma wczesna identyfikacja deficytów funkcji poznawczych współwystępujących z depresją, co umożliwia zastosowanie interwencji terapeutycznych optymalizujących codzienne funkcjonowanie osoby z wykorzystaniem właściwych strategii kompensacyjnych. Zaleca się ponawianie oceny funkcjonowania poznawczego seniorów w trakcie leczenia zaburzeń afektywnych oraz monitorowanie stanu poznawczego po zakończeniu terapii.

\section{BIBLIOGRAFIA}

Alexopoulos G.S., Kiosses D.N., Heo M., Murphy C.F., Shanmugham B., Gunning-Dixon F. (2005), Executive dysfunction and the course of geriatric depression, „Biol. Psychiatry”, Vol. 58(3), DOI: https://doi.org/10.1016/j.biopsych.2005.04.024.

Andersen G., Vestergaard K., Ingemann-Nielsen M., Lauritzen L. (1995), Risk factors for post-stroke depression, "Acta Psychiatrica Scandinavica”, Vol. 92(3),

DOI: https://doi.org/10.1111/j.1600-0447.1995.tb09567.x.

Barnes D.E., Yaffe K., Byers A.L., McCormick M., Schaefer C., Whitmer R.A. (2012), Midlife vs late-life depressive symptoms and risk of dementia: differential effects for Alzheimer disease and vascular dementia, "Archives of General Psychiatry", Vol. 69(5). 
Bhalla R.K., Butters M.A., Mulsant B.H., Begley A.E., Zmuda M.D., Schoderbek B., Pollock B.G., Reynolds C.F., Becker J.T. (2006), Persistence of neuropsychological deficits in the remitted state of late-life depression, "American Journal of Geriatric Psychiatry", Vol. 14(5),

DOI: https://doi.org/10.1097/01.JGP.0000203130.45421.69.

Bujnowska-Fedak M., Grata-Borkowska U., Sapilak B. (2012), Otępienie i depresja u pacjentów w podesztym wieku w Praktyce Lekarza Rodzinnego, "Fam. Med. Primary Care Rev.", Vol. 3.

Carson A.J., MacHale S., Allen K., Lawrie S.M., Dennis M., House A., Sharpe M. (2000), Depression after stroke and lesion location: A systematic review, "Lancet", Vol. 356,

DOI: https://doi.org/10.1016/S0140-6736(00)02448-X.

Colasanti V., Marianetti M., Micacchi F., Amabile G.M., Mina C. (2010), Tests for the evaluation of depression in the elderly: A systematic review, "Archives of Gerontology and Geriatrics", Vol. 50(2), DOI: https://doi.org/10.1016/j.archger.2009.04.001.

Diniz B.S., Butters M.A., Albert S.M., Dew M.A., Reynolds C.F. (2013), Late-life depression and risk of vascular dementia and Alzheimer's disease: Systematic review and meta-analysis of community-based cohort studies, "British Journal of Psychiatry", Vol. 202(5),

DOI: https://doi.org/10.1192/bjp.bp.112.118307.

Dobrzyńska E., Rymaszewska J., Kiejna A. (2007), Depresje u osób w wieku podeszłym, „Psychogeriatria Polska", $\mathrm{nr} 4(1)$.

DSM-5 (2013), Desk Reference to the Diagnostic Criteria from DSM-5, Washington-London: American Psychiatric Publishing.

Filipska K., Pietrzykowski Ł., Ciesielska N., Dembowski Ł., Kędziora-Kornatowska K. (2015), Zaburzenia depresyjne w podesztym wieku, „Gerontologia Polska”, nr 4.

Hackett M.L., Yapa C., Parag V., Anderson C.S. (2005), Frequency of depression after stroke. A systematic review of observational studies, "Stroke", Vol. 36(5),

DOI: https://doi.org/10.1161/01.STR.0000162391.27991.9d.

Hegeman J.M., Kok R.M., Mast R.C. van der, Giltay E.J. (2012), Phenomenology of depression in older compared with younger adults: Meta-analysis, "British Journal of Psychiatry", Vol. 200(4), DOI: https://doi.org/10.1192/bjp.bp.111.095950.

Herrmann L.L., Goodwin G.M., Ebmeier K.P. (2007), The cognitive neuropsychology of depression in the elderly, "Psychological Medicine", Vol. 37(12),

DOI: https://doi.org/10.1017/S0033291707001134.

Heszen I., Sęk H. (2000), Psychologia zdrowia, Warszawa: Wydawnictwo Naukowe PWN.

ICD-10 (1998), Klasyfikacja zaburzeń psychicznych i zaburzeń zachowania w ICD-10. Badawcze kryteria diagnostyczne, Kraków-Warszawa: Uniwersyteckie Wydawnictwo Medyczne „Vesalius", Instytut Psychiatrii i Neurologii.

Irzyniec T., Nowak-Kapusta Z., Franek G., Drzazga B. (2016), Osoby starsze objęte pielęgniarska domowa opieka dtugoterminowa, „Gerontologia Polska”, nr 24.

Janssen J., Hulshoff Pol H.E., Leeuw F.E. de, Schnack H.G., Lampe I.K., Kok R.M., Kahn R.S., (2007), Hippocampal volume and subcortical white matter lesions in late life depression: Comparison of early and late onset depression, "Journal of Neurology, Neurosurgery \& Psychiatry", Vol. 78(6), DOI: https://doi.org/10.1136/jnnp.2006.098087. 
Jodzio K., Wieczorek D., Radziwiłłowicz W. (1997), Psychologiczna ocena procesów uczenia się $w$ diagnozie różnicowej między depresją typu endogennego a rozlanym i rozsianym uszkodzeniem mózgu, „Postępy Psychiatrii i Neurologii”, nr 6.

Koenig A.M., Bhalla R.K., Butters M.A. (2014), Cognitive functioning and late-life depression, "Journal of the International Neuropsychological Society", Vol. 20(5),

DOI: https://doi.org/10.1017/S1355617714000198.

Kujawska-Danecka H., Nowicka-Sauer K., Hajduk A., Wierzba K., Krzemiński W., Zdrojewski Z. (2016), The prevalence of depression symptoms and other mental disorders among patients aged 65 years and older - screening in the rural community, "Family Medicine \& Primary Care Review", Vol. 3.

Kumar A., Bilker W., Lavretsky H., Gottlieb G. (2010), Volumetric asymmetries in late-onset mood disorders: An attenuation of frontal asymmetry with depression severity, "Psychiatry Res.", Vol. 100(1).

Manthorpe J., Iliffe S. (2010), Depresja wieku podeszłego, Warszawa: Wydawnictwo Lekarskie PZWL.

Nowak-Kapusta Z., Franek G., Leszczyńska K., Ćmiel-Giergielewicz M. (2017), Charakterystyka wybranych elementów sytuacji społeczno-zdrowotnej mieszkańców domów pomocy społecznej z uwzględnieniem występowania u nich objawów depresji, „Gerontologia Polska”, nr 25.

Nys G.M.S., Zandvoort M.J.E. van, Worp H.B. van der, Haan E.H.F. de, Kort P.L.M. de, Jansen B.P.W., Kappelle L.J. (2006), Early cognitive impairment predicts long-term depressive symptoms and quality of life after stroke, "Journal of Neurological Sciences", Vol. 247(2),

DOI: https://doi.org/10.1016/j.jns.2006.04.005.

Osińska M., Kazberuk A., Celińska-Janowicz K., Zadykowicz R., Rysiak E. (2017), Depresja - choroba cywilizacyjna XXI wieku, „Geriatria”, $\mathrm{nr} 11$.

Parnowski T. (2011), Zespoły depresyjne $w$ wieku podeszłym - archetyp zaburzeń afektywnych?, „Postępy Nauk Medycznych”, nr 8.

Rajtar-Zembaty A., Sałakowski A., Rajtar-Zembaty J., Starowicz-Filip A. (2017), Dysfunkcje wykonawcze w depresji wieku podeszłego, „Psychiatria Polska”, nr 51(4).

Richard B., Satahta P. (2004), Depression in later life: A diagnostic and therapeutic challenge, “Am. Fam. Physician”, Vol. 69(10).

Steffens D.C., Fisher GG., Langa K.M., Potter G.G., Plassman B.L. (2009), Prevalence of depression among older Americans: The aging, demographics and memory study, "International Psychogeriatrics”, Vol. 21(5), DOI: https://doi.org/10.1017/S1041610209990044.

Steuden S. (2011), Psychologia starzenia się i starości, Warszawa: Wydawnictwo Naukowe PWN.

Zarb J. (1996), Correlates of depression in cognitively impaired hospitalized elderly referred for neuropsychological assessment, "Journal of Clinical and Experimental Neuropsychology", Vol. 18(5), DOI: https://doi.org/10.1080/01688639608408294.

\section{SUMMARY}

Late-life depression is a serious and increasing problem in contemporary society, although it seems to be underestimated in clinical practice. It leads to high mortality, deteriorates general somatic condition, escalates disability and destroys patients' and their families' quality of life. 
Depressive symptoms may be difficult to identify and interpret in the elderly because other concomitant pathologies mask the signs of depression. In the article, the specific psychosocial background and clinical features of late-life depression were described. The diagnostic challenges and their sources were recognized. Depression-executive dysfunction syndrome and other cognitive deficits manifested by patients with late-life depression were characterized. Monitoring of patients' cognitive functioning was recommended in the course of late-life depression treatment.

Keywords: depression; elderly; cognitive impairment; depression-executive dysfunction syndrome; poststroke depression 